\title{
Science Studies and the History of Science
}

\author{
Lorraine Daston
}

\section{Introduction: Hard-hearted Adamant}

The current relation between science studies and the history of science brings to mind the opening scenes of A Midsummer Night's Dream (or, minus the fairies, the high school comedy of your choice): Helena loves Demetrius, who used to love Helena, but now loves Hermia, who loves Lysander. A perfervid atmosphere of adolescence hangs over the play: rash promises, suicide threats, hyperbolic but sincere pledges of love and enmity, and, above all, the breathless sense of everything being constantly up for grabs.

Transposed from the enchanted wood of Oberon and Titania to the disenchanted groves of academe, it is science studies that fancies itself in the role of the spurned Helena, once courted but now rejected by the history of science. Sheila Jasanoff, speaking qua president of the Society for the Social Studies of Science, recently complained of a "somewhat onesided love affair" with the history of science and a certain "jitteriness about being caught out in risque company [that] marks the hiring practices of our major history of science departments." While her society has awarded some of its highest prizes to historians of science, those ungrateful Demetriuses were off flirting with the discipline of history, which in turn was in hot pursuit of cultural anthropology. What fools these mortals be. Yet there was a time when Helena was wooed by Demetrius, and the history of science once was smitten by science studies. The story of infatuation and subsequent estrangement follows, I suspect, a more general pattern in the

1. Sheila Jasanoff, "Reconstructing the Past, Constructing the Present: Can Science Studies and the History of Science Live Happily Ever After?" Social Studies of Science 30 (Aug. 2000): 623,622 .

Critical Inquiry 35 (Summer 2009)

(C) 2009 by The University of Chicago. 0093-1896/09/3504-0008\$10.00. All rights reserved. 
relation between disciplines and interdisciplinary clusters that address the same subject matter-in this case, science and technology. My aim in this essay is to trace that pattern.

This is a crepuscular undertaking. The owl of Minerva flies only at twilight, as Hegel said. Put less poetically, reflection begins when bedazzlement ends. It would be absurd to claim that science studies has entered its last days and still more ludicrous to suggest that a cold shoulder from the history of science has decreased the attractions of science studies in other quarters. But the leaders of science studies themselves bemoan a lack of vigor, even a crisis, in their field. David Edge, founder of the pioneering Science Studies Unit at the University of Edinburgh in 1966, elegiacally asks, "Has the heady sense of interdisciplinary adventure, of the seductive combination of academic priority and practical urgency, disappeared for good?"2 Bruno Latour, who studied laboratory life the way ethnographers might study a tribe in Papua New Guinea and whose actor-network theory dissolved the distinction between humans and nonhumans, has come close to a recantation, "but, fortunately (yes, fortunately!), one after the other, we witnessed that the black boxes of science remained closed and that it was rather the tools [of science studies] that lay in the dust of our workshop, disjointed and broken. Put simply, critique was useless against objects of some solidity." 3 Admittedly, Edge and Latour are wringing their hands over different disasters; Edge, like Jasanoff, sighs over the fact that

2. David Edge, "Reinventing the Wheel," in Handbook of Science and Technology Studies, ed. Jasanoff et al. (Thousand Oaks, Calif., 1995), p. 3.

3. Bruno Latour, "Why Has Critique Run out of Steam? From Matters of Fact to Matters of Concern," Critical Inquiry 30 (Winter 2004): 242.

LORRAINE DASTON is the director of the Max Planck Institute for the History of Science in Berlin and visiting professor in the Committee on Social Thought at the University of Chicago. At the Max Planck Institute she has organized research projects on the history of demonstration and proof, the varieties of scientific experience, the moral authority of nature, the common languages of art and science, and the history of scientific observation. Edited volumes resulting from these projects include Biographies of Scientific Objects (2000), The Moral Authority of Nature (2004) (coedited with Fernando Vidal), and Things That Talk: Object Lessons from Art and Science (2004). Her books include Classical Probability in the Enlightenment (1988) and, with Katharine Park, Wonders and the Order of Nature, 1150-1750 (1998), both of which were awarded the Pfizer Prize of the History of Science Society. Objectivity, coauthored with Peter Galison, was published in 2007. She is currently working on a book about the link between moral and natural orders. 
the insights of science studies have been studiously ignored by those who have the most to learn from them, while Latour suspects that there is little to be learned. Neither, however, is stridently confident about the present and future of science studies.

What has happened to the fizz and feistiness of science studies, once the most ebullient of interdisciplinary ventures? Où sont les programmes forts d'antan? How has it drifted apart from the history of science, its former muse and claque? What can these developments tell us about disciplinarity-its preconditions, its practices, its ethos? In the short compass of this essay I can offer no more than sketchy answers to these questions. I shall argue that despite intensive and fruitful exchanges between science studies and the history of science in the 1970 s and 1980s the two fields came to diverge in their conceptions of what they initially had held in common, namely, the subject matter of science. I shall first set the scene with a very brief, highly selective, and no doubt maddeningly tendentious account of the relations between science studies and the history of science since circa 1970 and then examine how their paths forked in the 1990s, as the history of science became ever more historical and science studies ever less. My conclusion reflects on the morals of this tale for understanding science-still the shared and urgent challenge to both science studies and the history of science. ${ }^{4}$

\section{A Very Short and Partial Relation of a Relationship}

Science studies is the mercifully short and clear abbreviation for a battery of disciplinary perspectives turned upon science and technology: first and foremost sociology, but also anthropology, political science, philosophy, gender studies, and history. It overlaps with but is not identical to Science, Technology, and Society programs, on the one hand, and the Sociology of Scientific Knowledge on the other. Both STS and SSK (science studies has a mania for acronyms that rivals that of federal bureaucracies) represent powerful and not always consistent impulses within science studies: on the STS side of things, an urgent desire for more rational science policy and for more broadly educated and socially responsible scientists and engineers; on the SSK side, a radical critique of the epistemological claims of science and technology to social authority. Depending on which of these natal stars was in the ascendant, science studies aimed either to humanize science by

4. For a brief overview of the history of science studies, see Edge, "Reinventing the Wheel," pp. 3-23. And for the history of science, see Lorraine Daston, "History of Science," in International Encyclopedia of the Social and Behavioral Sciences, ed. Neal J. Smelser and Paul B. Baltes, 26 vols. (New York, 2001), 10:6842-48. 
making it more social (or at least sociable) or to tame it, also by making it more social (or at least sociological).

The iridescent word social was and remains the talisman of science studies. (Its flagship journal, Science Studies, was soon rechristened Social Studies of Science.) The adjective social was conveniently protean, depending on which noun it modified. It could signify sobriety and conscience (as in "the social responsibility of science"), complexity and connectivity (as in "the social context of science"), or devastating critique (as in "the social construction of science"). In all of these registers the resonances of the social were resolutely Durkheimian in their repudiation of anything smacking of psychology (which was not merely an accidental omission from the list of disciplinary approaches encircled by science studies' otherwise ample embrace). The emphasis was on institutions and structures, not individuals and agency. Moreover, especially in its critical cadences, the social drew heavily upon the debunking strategies of Marxist approaches to ideology. To reveal that a scientific category (for example, race) or a scientific claim (for example, the passivity of the ovum in human conception) was socially constructed was ipso facto to challenge its validity and to imply a covert political agenda. ${ }^{5}$

As these affinities suggest, science studies could and did retrospectively lay claim to a distinguished lineage: not only Karl Marx and Émile Durkheim but also Karl Mannheim's sociology of knowledge, Ludwik Fleck's philosophy-cum-sociology of biomedical research, J. D. Bernal's Marxist approach to science policy, Mary Douglas's cultural anthropology, Ludwig Wittgenstein's philosophical reflections on rules and forms of life, and Michael Polanyi's explorations of "personal knowledge" in science. But as a self-conscious field of inquiry science studies first came into being in the 1970s, and its touchstone text was a work in the history of science: Thomas S. Kuhn's The Structure of Scientific Revolutions. ${ }^{6}$

This book took the social sciences—as well as of course the history and philosophy of science- by storm and generated almost as many readings as readers. Science studies was no exception to this multiplication of interpretations. But, from the outset, one reading in particular stamped science studies and, more specifically, the sociology of scientific knowledge: the self-avowed "strong programme" developed by the brilliant Science Studies Unit at the University of Edinburgh (which included the sociologist Barry Barnes, the philosopher David Bloor, and the historians Steven

5. See Ian Hacking, The Social Construction of What? (Cambridge, Mass., 1999), which offers the most lucid account and analysis of social constructionism and its impact.

6. See Thomas S. Kuhn, The Structure of Scientific Revolutions (1962; Chicago, 1970). 
Shapin and Donald MacKenzie). The strong programme has given rise to a hermeneutics almost as variegated and convoluted as that spawned by Kuhn's The Structure of Scientific Revolutions, and I intend neither to rehearse nor to enlarge that literature here. ${ }^{7}$ For my purposes it is enough to draw attention to one key component, namely, the a priori postulate that no satisfactory account of why some scientific claims triumphed over others could appeal to the truth or superior epistemological solidity of the winning claims. From the standpoint of explanation in science studies, the truth or falsehood of scientific beliefs was symmetric. Neither property was a sufficient explanation for how and why scientists came to hold the beliefs they did rather than the alternatives. ${ }^{8}$ With the "symmetry principle" (science studies vied with theology in its doctrinal fondness for principles, theses, and programs), scholars in science studies interpreted Kuhn's analysis as a manifesto of relativism - an interpretation they shared with many philosophers of science with whom they were at loggerheads on almost every other issue. ${ }^{9}$

Historians of science drew a somewhat different lesson from Kuhn's book, one probably more in tune with Kuhn's own views, namely, that teleology must be repudiated as a narrative form in the history of science. The history of science could no longer be understood as the steady progress toward some end, an ever-closer approximation of the truth about nature. At best what Kuhn had called normal science made progress in problem solving in its own terms - terms that did not survive scientific revolutions, which rewrote the rules of the game. By implication, historians of science would have to abandon the language of winners and losers, the segregation of sheep from goats—Lavoisier sheep, Priestley goat; Darwin sheep, Lamarck goat, the litany of my undergraduate teachers-and the winnowing of truth from error. ${ }^{10}$ Instead, they must strive to understand the science of the past in its own terms, reconstructing the reasonableness if not the timeless rationality of the arguments on all sides.

At first it seemed as if the difference between these two interpretations

7. For an overview, see Jan Golinski, Making Natural Knowledge: Constructivism and the History of Science (Cambridge, 1998).

8. See Barry Barnes, Scientific Knowledge and Sociological Theory (London, 1974) and T. S. Kuhn and Social Science (London, 1982), and David Bloor, Knowledge and Social Imagery (London, 1976).

9. Kuhn confronted his critics among the philosophers in "Reflections on My Critics," in Criticism and the Growth of Knowledge, ed. Imre Lakatos and Alan Musgrave (Cambridge, 1970), pp. 231-78.

10. On changing narratives in the history of science since the eighteenth century, see Daston, "The Historicity of Science," in Historicization-Historisierung (Göttingen, 2001), pp. 201-21. 
was slight. The common enemy of both science studies and the history of science was a positivist vision of science as a compound of logic and empiricism, rigorously defined by a more or less mechanical method and sharply demarcated from both ambient society and less-successful intellectual pursuits like theology or astrology. Moreover, both symmetry and science in context turned scholarly attention toward scientific controversy and the interaction of science and society as promising sites of inquiry. This promise was abundantly fulfilled with a bumper crop of remarkable studies of how scientists reached consensus in both the past and the present. ${ }^{11}$ Contacts between science studies and the history of science, particularly in Great Britain among the programs in Edinburgh, Bath, and Cambridge, were close and mutually stimulating, if not always harmonious. On the continent, the ethnographic approaches to the laboratory of Latour in France and Karin Knorr Cetina in Germany imparted a strong impulse to the study of minute, concrete practices in the history of science. ${ }^{12}$ In North America, science studies was invigorated by feminist theory $^{13}$ and political movements launched by scientists themselves. ${ }^{14}$ The 1980 s crackled with debate-much of it sharp, some of it sparkling, all of it animated. For the first time in living memory, meetings of the History of Science Society were punctuated by raised voices rather than by gentle snoring. Science studies burgeoned; the history of science was transformed.

The political implications of these academic discussions never lay far from the surface. Societies saturated with science and technology were offered a whole new optic to view their past development and present

11. Among the most influential empirical monographs were H. M. Collins, Changing Order: Replication and Induction in Scientific Practice (London, 1985); Steven Shapin and Simon Schaffer, Leviathan and the Air-Pump: Hobbes, Boyle, and the Experimental Life (Princeton, N.J., 1985); Martin J. S. Rudwick, The Great Devonian Controversy: The Shaping of Scientific Knowledge among Gentlemanly Specialists (Chicago, 1985); and Trevor J. Pinch, Confronting Nature: The Sociology of Solar-Neutrino Detection (Dordrecht, 1986).

12. See Latour and Steve Woolgar, Laboratory Life: The Social Construction of Scientific Facts (1979; Princeton, N.J., 1986), and Latour, Science in Action: How to Follow Scientists and Engineers through Society (Cambridge, Mass., 1987). See also Karin D. Knorr Cetina, The Manufacture of Knowledge: An Essay on the Constructivist and Contextual Nature of Science (Oxford, 1981).

13. See Carolyn Merchant, The Death of Nature: Women, Ecology, and the Scientific Revolution (San Francisco, 1980); Donna Haraway, Primate Visions: Gender, Race, and Nature in the World of Modern Science (New York, 1989); and Londa Schiebinger, The Mind Has No Sex? Women in the Origins of Modern Science (Cambridge, Mass., 1989).

14. See Stephen Jay Gould, The Mismeasure of Man (New York, 1981); Richard C. Lewontin, Steven Rose, and Leon J. Kamin, Not in Our Genes: Biology, Ideology, and Human Nature (New York, 1984); and Jonathan R. Beckwith, Making Genes, Making Waves: A Social Activist in Science (Cambridge, Mass., 2002). 
choices. Many scholars in science studies were openly and ardently engaged in political debates about science, technology, and medicine. All were acutely aware that the symmetric analysis of scientific controversies, even if conducted from a position of neutrality, had the overall effect of strengthening the losing side by taking its arguments far more seriously than reigning scientific orthodoxy would. ${ }^{15}$ Between 1985 and 1995 , contingent, negotiation, and work were the refrain of the most provocative work in science studies and the history of science. The course of scientific development and the outcome of scientific controversies was contingent; everything from consensus about rival scientific theories to the definition of scientific entities was negotiated among parties with opposed interests; and apparently Gibraltar-firm scientific findings and facts actually had to be stabilized by a great deal of work. In short, nothing was self-evident, straightforward, or secure; even the data were no longer a given.

Some scientists found this irritating, even blasphemous, ${ }^{16}$ but most were simply puzzled or bored. They stopped reading the history of science. Few ever started reading science studies, unless they were directly involved in the controversies being studied. Those few scientists, especially in the United States, who paid science studies the left-handed compliment of holding its unsettling effects responsible for the cancellation of their research funding had to reckon with the mammoth improbability of a congressman or senator being immersed in the work of Latour or Donna Haraway. The furor unleashed by the Sokal affair was far stormier in the humanities than in the sciences and in any case blew over quickly. ${ }^{17}$ The causes of science studies and the history of science parting ways in the mid-1990s lay elsewhere, in the ways in which they understood their shared object of inquiry and practiced their crafts of research and explanation.

\section{What Is Science?}

It is easier to pinpoint exactly when Demetrius dumped Helena than when the relation between science studies and the history of science became more distant. But by the end of the 1990 s it was an open secret. In a plenary address delivered in 1999 to a joint session of the Society for the

15. See Pam Scott, Evelleen Richards, and Brian Martin, "Captives of Controversy: The Myth of the Neutral Social Researcher in Contemporary Scientific Controversies," Science, Technology, and Human Values 15 (Oct. 1990): 474-94.

16. See Paul R. Gross and Norman Levitt, Higher Superstition: The Academic Left and Its Quarrels with Science (Baltimore, 1994).

17. See Science Wars, ed. Andrew Ross (Durham, N.C., 1996); Alan D. Sokal and Jean Bricmont, Intellectual Impostures: Postmodern Philosophers' Abuse of Science (London, 1998); and The Sokal Hoax: The Sham That Shook the Academy, ed. the editors of Lingua Franca (Lincoln, Nebr., 200o). 
Social Studies of Science and the History of Science Society, commemorating the twenty-fifth anniversary of the former society and the seventyfifth anniversary of the latter, Jasanoff observed that she and her coeditors of the Handbook of Science and Technology Studies (1995) had found contributors in "sociology, anthropology, philosophy, political science, rhetoric, women's studies, to name a few. Only history is strangely absent." ${ }^{18}$ Her lecture was auspiciously subtitled, "Can Science Studies and the History of Science Live Happily Ever After?" but the doubts that justified the question mark in 1999 would have been barely conceivable a decade earlier. What had happened in the interim?

After Kuhn, both science studies and the history of science deliberately adopted a position of estrangement toward contemporary science, but they did so for different reasons that ultimately led to divergent understandings of science and how to study it. Science studies refused to accept on faith the claim that current scientific doctrine had come to be widely accepted because it was true or at least truer than any of the extant alternatives. First of all, science studies analysts argued, the truth or falsehood of a proposition was neither a sufficient nor necessary explanation (as opposed to a reason, in the philosophical sense) for its acceptance. Second, a full-dress explanation often involved social and political as well as cognitive factors, regardless of what scientists may report (and sincerely believe) about their exclusive adherence to the latter. In its most extreme form, science studies' estrangement aspired to the tabula rasa perspective of visiting Martians, to whom everything was alien and who could take nothing for granted. The aim of science studies' estrangement was transparency; by steadfastly and warily refusing to privilege the scientists' own accounts of how they did what they did, analysts sought to crack open the "black boxes" of science and technology that had been opaque to public scrutiny_-and hence to public surveillance.

Historians of science entertained fewer suspicions about the deceptions or self-deceptions of contemporary scientists apropos of current science. But historians were deeply skeptical about descriptions of past science in terms of present science. It was all very well for the chemist or mathematician down the hall to report on his or her research just as he or she saw it; it was, however, an invitation to distortion to translate the work of, say, Robert Boyle or Leonhard Euler into modern terms or notation. Such translations almost always occluded the pastness of the past, the strange-

18. Jasanoff, "Reconstructing the Past, Constructing the Present," p. 622. Conversely, when Jasanoff refereed "History of Science," an article I had authored for the new edition of the International Encyclopedia of the Social and Behavioral Sciences, she remarked upon the absence of science studies references. 
ness that made the history of science genuinely historical. Historians of science had come to fear, albeit belatedly by the standards of general history, the besetting sin of anachronism, the equivalent of ethnocentrism in anthropology and anthropocentrism in ethology. They refused the accounts of present science so that they could immerse themselves in past science. Although they too, like the ethnographers of the laboratory, might have imagined themselves as strangers in a strange land, they saw no reason to distrust the natives. On the contrary, historians of science wanted to understand chemistry (or rather "chymistry") as Boyle had, not to trump his explanation with one of their own. This is probably the principal reason (rather than any political antipathy) why scientists stopped reading the history of science; it had succeeded all too well in making past science wholly unfamiliar, even (or especially) to a reader well versed in present science.

The contextualization of science also pulled science studies and the history of science in different directions. When science studies trumpeted the motto "science in context," what was implied was an end to science's alleged autonomy and hegemony with respect to ambient society. Science was shot through with social interests and political struggles; it was the job of science studies to lay them bare. Originally, studies in the history of science that hoisted the banner of "science in context" had similar ambitions. ${ }^{19}$ But the exploration of historical context gradually broadened and deepened to include concepts and categories unheard of in the social sciences, at least in their Anglo-American branches.

It was precisely the historians of science who specialized in premodern (ancient, medieval, and early modern) periods who were most at pains to distinguish not only past from present science but also past from present society. Insofar as they looked to sociology for inspiration it was to the likes of Norbert Elias on court society or Marcel Mauss on gift exchanges, ${ }^{20}$ not to theories of class interest or actor networks. Culture replaced society in their titles. Science at the court of Rudolf II in Prague or Cosimo de Medici in Florence was certainly enmeshed in politics, but it was the politics of patronage and symbolic display, not that of grantsmanship and industrial contracts. Historians of premodern science grew increasingly skittish about calling what they studied science at all, and the word scientist when applied to Archimedes or Galileo set their teeth on edge. This was not so

19. See, for example, Natural Order: Historical Studies of Scientific Culture, ed. Barnes and Shapin (Beverly Hills, Calif., 1979).

20. See, for example, Mario Biagioli, Galileo, Courtier: The Practice of Science in the Culture of Absolutism (Chicago, 1993), and Paula Findlen, Possessing Nature: Museums, Collecting, and Scientific Culture in Early Modern Italy (Berkeley, 1994). 
much finickiness (although it was also that) as a desire to capture lost disciplines (scientia, natural philosophy, mixed mathematics) and personae (courtier, sage, philosopher) that were crucial for accurate historical reconstructions.

In his introduction to the The Science Studies Reader, Mario Biagioli (not coincidentally a historian of early modern science) perceptively remarked that the position of science studies with respect to its object of inquiry is unusual:

Science studies does not define its subject matter because, in some significant way, its subject matter comes pre-packaged. It is not that science studies practitioners are obliged to study only what scientists take to be the fundamental aspects of their enterprise (actually the opposite is often true), but simply that science-as the set of scientists' practices, institutions, and so on-remains a socially delineated object no matter how you look at it. As a result, science studies tends not to ask what science is but rather how science works. ${ }^{21}$

Among historians of science, only specialists in the twentieth century can allow themselves to take their subject matter for granted, and even they ponder the "disunity of science" in their period. ${ }^{22}$ All other historians of science are crucially concerned with what science is, as well as how it works.

This is not primarily because historians of science are exercised by what philosophers used to call the demarcation criterion-how scientific knowledge differs from all other candidates for genuine knowledge- but rather because they study natural knowledge before science and scientists as we now know them came into being. They do not doubt the distinctive character of science, but they must explain how that character crystallized-slowly, falteringly, contingently-out of practices, both intellectual and manual, designed for other purposes: the artisanal trials of materials that became the laboratory; the humanist letter that became the journal article; the princely Wunderkammer that became the natural history museum; the legal arguments from indices that became probabilistic arguments from evidence; the engineering feats in ballistics and shipbuilding that became rational mechanics. More generally, the challenge to historians of science before science became "pre-packaged" is to explain how local knowledge-for contextualized knowledge is always rooted in a par-

21. Biagioli, "Introduction: Science Studies and Its Disciplinary Predicament," in The Science Studies Reader, ed. Biagioli (New York, 1999), p. xii.

22. See Peter Galison and David J. Stump, The Disunity of Science: Boundaries, Contexts, and Power (Stanford, Calif., 1996). 
ticular place and time-became universal science, that is, how context eventually erased itself. History of science attempts to pry open the one black box science studies accepts from science without peering inside.

The divergence of positions (estrangement as sociological suspicion versus estrangement as historical Verstehen) and subject matter (science as the given versus science as the explanandum) has led to still more striking divergence in practices. Science studies is ecumenical, drawing on a broad range of the social sciences and humanities for its empirical material and methods. The development, refinement, and testing of these methods has largely been left to the home disciplines from which they have been imported. The borrowed methods of what is dryly described as data collection and analysis are assumed to be reliable, unproblematic, and perhaps a bit pedestrian. Science studies analysts, however, locate their own contribution in the domain of "methods of explanation." ${ }_{23}$ Twenty years ago historians of science also pieced together a collage of approaches, prompting one of its most distinguished practitioners to wonder "whether the history of science is a coherent discipline or just a collection of scholars aggregated by the accidents of history and the accretion of a common historiography." ${ }^{24}$ But since then, in large part because of the mandate to embed science in context, historians of science have become selfconsciously disciplined, and the discipline to which they have submitted themselves is history.

In the 1980 and 1990s, an increasing number of historians of science received supplementary training in history at the doctoral level, were initiated into the rites of archival research, and were subsequently hired by history departments. Spurred both by collegial contacts and the experience of teaching general history courses, these historians of science began a serious inquiry into the context in which science was embedded and began to worry about the anachronisms and teleology that riddled older work in their field. Like other historians in these decades, historians of science responded to the cultural turn, but with a twist; steeped in the work of Pierre Bourdieu and, closer to home, the close-up studies of the laboratory, they interpreted "culture" less in terms of symbols and values than in those of bodily gestures, mental habits, sensory training, the making of images, and the manipulation of materials. This focus had the great advantage of dissolving the onerous division between "internal" and "external" history of science; highly technical procedures (for example, how to

23. Gary Bowden, "Coming of Age in STS: Some Methodological Musings," in Handbook of Science and Technology Studies, p. 65.

24. Charles Rosenberg, "Woods or Trees? Ideas and Actors in the History of Science," Isis 79 (Dec. 1988): 570. 
make precision measurements at high temperatures) might turn out to stem from cultural competences (for example, brewing beer). ${ }^{25}$ More subtly but inexorably, immersion in the scientific practices that eventually created scientific disciplines led - by a kind of mimesis - to historical practices that turned the history of science into a discipline.

In this fashion, historians of science mastered the practices and adopted the ethos of historians. The impact of their disciplinary apprenticeship is most clearly seen in the handiwork and heft of work produced in the past decade. The improved craftsmanship of the footnotes alone would signal a steep rise in disciplinary standards-footnotes being to historians what joints are to carpenters, that is, the place where the trained eye looks first to test the quality of workmanship. ${ }^{26}$ There has also been a marked shift in genre and texture in recent historiography of science, again following the lead of general historians. Gone are the case studies in support of one or another grand philosophical or sociological generalization about the nature of science; in their place a swarm of microhistories have descended, often archivally based and narrated in exquisite detail. In the hands of a virtuoso like Natalie Zemon Davis or Carlo Ginzburg a microhistory can see the universe in a grain of sand, illuminating cosmic themes on hand from a single, richly described episode. ${ }^{27}$ Alas, virtuosi are rare in all fields, and the average microhistory in the history of science places the accent heavily on the "micro"; the texture is fine-grained, the metaphysics is nominalist, the aesthetic is pointillist. The call from science studies to heed context and practices has been followed with a vengeance by historians of science who apprenticed themselves to historians to do so-with the paradoxical result that the history of science and science studies have ever less to say to one another.

Insofar as there has been a counterweight to these miniaturizing tendencies in recent work in the history of science, it has been supplied not by science studies but by a still more thoroughgoing form of historicism, namely, the philosophical history of Michel Foucault. Foucault was himself trained by the French historian of science Georges Canguilhem, so there was a kind of prearranged harmony between the topics Foucault originally set out to historicize so radically—madness, natural history,

25. For this particular example, see H. Otto Sibum, "An Old Hand in a New System," in The Invisible Industrialist: Manufactures and Productions of Scientific Knowledge, ed. Jean-Paul Gaudillière and Ilana Löwy (Houndmills, 1998), pp. 23-57.

26. The history of scientific and scholarly practices has produced a study of the footnote. See Anthony Grafton, The Footnote: A Curious History (Cambridge, Mass., 1997).

27. On the implications of "thinking by cases" in history, see Penser par cas, ed. JeanClaude Passeron and Jacques Revel (Paris, 2005). 
biopower-and the traditional preoccupations of historians of biomedicine. But the shock waves triggered by Foucault's concerted attempts to write the history of the ahistorical-sexuality, the self, truth itselfreached far beyond the human and life sciences. ${ }^{28}$ Topics like proof, experience, and objectivity, which historians had previously assigned to the timeless contemplations of the philosophers, suddenly seemed fair game. Moreover, the Foucauldian mode of historical investigation of these ethereal abstractions was painstakingly concrete, dovetailing with the new disciplinary consciousness of historians of science. It was close reading, archival burrowing, and minute inquiry into specific practices, not philosophical argument or sociological analysis, that would yield up the invisible history of objects that had become inevitable, providing the evidence for the history of the self-evident.

Once again, projects in the history of science that had been set in motion by impulses from science studies-for example, the ethnography of experiment or the construction of scientific facts-veered off in a new direction once historicized, as in the case of the history of scientific experience. ${ }^{29} \mathrm{It}$ is, for example, a commonplace that appeals to experience became a kind of epistemological bedrock by the late seventeenth century. But what kind of experience exactly? What were its forms, its origins, its practices? How did the machines envisioned in treatises on rational mechanics relate to the working machines being used to erect obelisks in Rome or unload ships in Amsterdam; the experimental demonstrations performed in Isaac Newton's rooms in Trinity College, Cambridge or before the assembled company of the Académie Royale des Sciences in Paris to the "proofs" of artisans; the rapturous attentiveness of a Robert Boyle or a Jan Swammerdam making an observation to the religious observances of the devout? This is epistemology in the making, and it looks nothing like what either the philosophy of science or science studies would understand under that rubric. Simply put, the more historical the history of science

28. On Foucault's impact on history, see Foucault and the Writing of History, ed. Jan Goldstein (Cambridge, Mass., 1994).

29. Seminal book-length studies include Shapin and Schaffer, Leviathan and the Air-Pump; Krzysztof Pomian, Collectionneurs, amateurs et curieux: Paris, Venise, XVIe-XVIIIe siècle (Paris, 1987); Galison, How Experiments End (Chicago, 1987); The Uses of Experiment: Studies in the Natural Sciences, ed. David Gooding et al. (Cambridge, 1989); Giuseppe Olmi, L'Inventario del mondo: Catalogazione della natura e luoghi del sapere nella prima età moderna (Bologna, 1992); Alain Desrosières, La Politique des grands nombres: Histoire de la raison statistique (Paris, 1993); Findlen, Possessing Nature; Peter Dear, Discipline and Experience: The Mathematical Way in the Scientific Revolution (Chicago, 1995); Christian Licoppe, La Formation de la pratique scientifique: Le Discours de l'expérience en France et en Angleterre (1630-1820) (Paris, 1996); and Harry M. Marks, The Progress of Experiment: Science and Therapeutic Reform in the United States, 19001990 (Cambridge, 1997). 
became the less the science it studied resembled the prepackaged subject matter of science studies.

\section{Conclusion: Beyond Realism and Relativism}

The bald conclusion I draw from the developments I have so telegraphically described is that the history of science (somewhat to its own surprise) has in the last decade or so become a discipline, with cultivated practices and an ethos, while science studies has remained interdisciplinary-and, even on the testimony of some insiders, undisciplined. This is not a development that the usual institutional indicators would necessarily register. Although I have not counted, I suspect that science studies worldwide counts at least as many, if not more, university positions, specialist journals, and scholarly societies as the history of science. Moreover, historians of science fret constantly that they are not sufficiently recognized by general historians despite the rapprochement of methods and perspectives that has occurred in recent years-Demetrius pursuing indifferent Hermia. But it is the ways in which graduate students are trained, the grounds upon which young scholars are hired and tenured, and, above all, the works that are read and emulated that reveal core academic values. All of these indices point toward a less eclectic, more classically disciplined history of science, closely modeled on history, albeit still more permeable to other influences and inspirations. ${ }^{30}$ (Reflexively, one might argue that this definition of a discipline in terms of its practices and ethos rather than its institutions is itself the fruit of the newly disciplined history of science.) In contrast, science studies, despite handbooks and annual meetings, still is self-described as "marginal" and "adolescent"—sometimes in exasperation, sometimes in defiance, but always polemically, with the full and usually justified expectation of being contradicted by a colleague. ${ }^{31}$

But an outside observer - a philosopher, perhaps, or a philosophically inclined scientist - might demur, contending that the history of science

30. As a historian of science, I am not convinced that this turn of affairs is an unadulterated good. Until recently, individual career paths into the history of science were usually sinuous rather than straight, and the field was a haven for people from every corner of the academic map who wanted to combine the technical with the hermeneutic, the particulars of history with the universals of philosophy, and thick description with sharp analysis. This blend gave the history of science a certain yeastiness that at once intrigued and rattled the neighboring disciplines of history, philosophy, and sociology, as well as the sciences. Some of what was produced was audacious and brilliant; much was unreadable, even at the time. The current history of science is almost always readable, engaging and instructive even, but curiously inert-finely wrought but flat. The price of disciplinarity has been a convergence toward the mean; fewer clunkers, but also fewer meteors.

31. Contrast, for example, the articles by Bowden, "Coming of Age in STS," and Richards, “(Un)Boxing the Monster," Social Studies of Science 26 (May 1996): 64-79, 323-56. 
and science studies are still united in a relativist campaign against science. For such critics it hardly matters whether the relativism in question is the social constructionism of science studies or the historicism of the history of science. Relativism is relativism, they will insist, and it corrodes all that it touches. Some scholars in science studies seem to have come around to this view as well. Latour writes feelingly about how criticism sullies all that we hold dear; would we willingly consign "our own valuables to their [the critics'] sordid pawnshop"?32 Malcolm Ashmore finds it "embarrassing" when science studies finds itself on the side of big tobacco corporations in a suit brought by a dying smoker, on the grounds that what now counts as persuasive scientific proof about the dangers of smoking didn't count back then. ${ }^{33}$ A recent issue of the Cornell University Department of Science and Technology Studies Newsletter carries a broadside against intelligent design that contests "the view, held by some in the scientific community, that science studies undermines science." 34

These doubts and self-doubts are, in my opinion, more accurately aimed at science studies than at the history of science for the paradoxical reason that science studies has remained closer to the sciences. Not only have the methods of science studies often been self-consciously scientistic (riddled with "principles" and a faith in empirical data that at times parodies positivism) ${ }^{35}$ but its philosophical assumptions are Manichean, like those of many scientists. On this account, if actual science can be shown not to conform to the accounts set forth in textbooks or the treatises of logical empiricists, the only alternative is wanton fabrication or ideology. If facts are not discovered, then they are ipso facto invented. To claim that science is socially constructed is to impugn both validity and honesty. I caricature, of course, but only slightly. When science studies tried to crack the black boxes of science and technology, the word transparency often implied "unmasking."

In contrast, to historicize the category of the fact, objectivity, or proof is not thereby to debunk it, no more than to write the history of the special theory of relativity thereby undermines it. This is a point perhaps made more easily in ethics than in epistemology; the fact that the judicial ban on torture arose in a specific historical context carries no weight in arguments

32. Latour, "Why Has Critique Run out of Steam?" p. 241.

33. See Malcolm Ashmore, "Ending up on the Wrong Side: Must the Two Forms of Radicalism Always Be at War?" Social Studies of Science 26 (May 1996): 305-22.

34. Kevin Lambert, "Opinion Piece: Intelligent Design," Cornell University Department of Science and Technology Studies Newsletter (Spring 2006): 15.

35. See, for example, Collins's defense of "scientific criteria" in "In Praise of Futile Gestures: How Scientific Is the Sociology of Scientific Knowledge?" Social Studies of Science 26 (May 1996): 229-44. 
concerning its moral validity. Analogously, the fact that scientific objectivity arose in a specific historical context neither supports nor undercuts its epistemological validity. "If historical, then relative" is a non sequitur. Why then do so many philosophers (as well as scientists, sociologists, and, yes, historians) nonetheless believe it follows? Why has historicism, especially in its Foucauldian form, been so consistently conflated with relativism?

To do these questions justice would require another essay, yea, another book. Here I can do no more than suggest lines of inquiry. Certain epistemological categories have become so fundamental to modern ways of knowing that they have been paid the dubious philosophical compliment of being made eternal-much like the Romans used to deify their emperors-because eternity and immutability, according to an ancient Platonic prejudice, designated the ontos on, the really real. Even though many, if not most, philosophers have broken with Platonism, the characteristic practices of their own discipline instill the view that the genuinely philosophical is that which withstands the ravages of time-those passages of Aristotle, Aquinas, Descartes, or Kant that can be understood by a sufficiently intelligent undergraduate with no further historical background. ${ }^{36}$

Historians of science, for their part, rarely reflect on such matters. Probably most historians of science these days, if asked about an episode like the refinement of precision measurement techniques or the formulation of statistical correlations, would answer that such scientific practices are both socially constructed and real. That is, they depend crucially on the cultural resources at hand in a given context (mid-nineteenth-century industrializing Prussia, early twentieth-century eugenics-obsessed Britain) and they capture some aspect of the world; they work. But they are neither historically inevitable nor metaphysically true. Rather, they are contingent to a certain time and place yet valid for certain purposes.

As of yet, a new vision of what science is and how it works has yet to be synthesized from the rich but scattered and fragmented materials gathered by some twenty years of historicized history of science. The very practices that made that history possible militate against such a synthesis coming from the history of science itself. Science studies seems a still less likely candidate for the task. A new form of interdisciplinarity must be forged. Philosophy, anyone?

36. For the ferocious debate sparked by a more genuinely historical approach to the history of philosophy, see Teaching New Histories of Philosophy, ed. J. B. Schneewind (Princeton, N.J., 2004). 


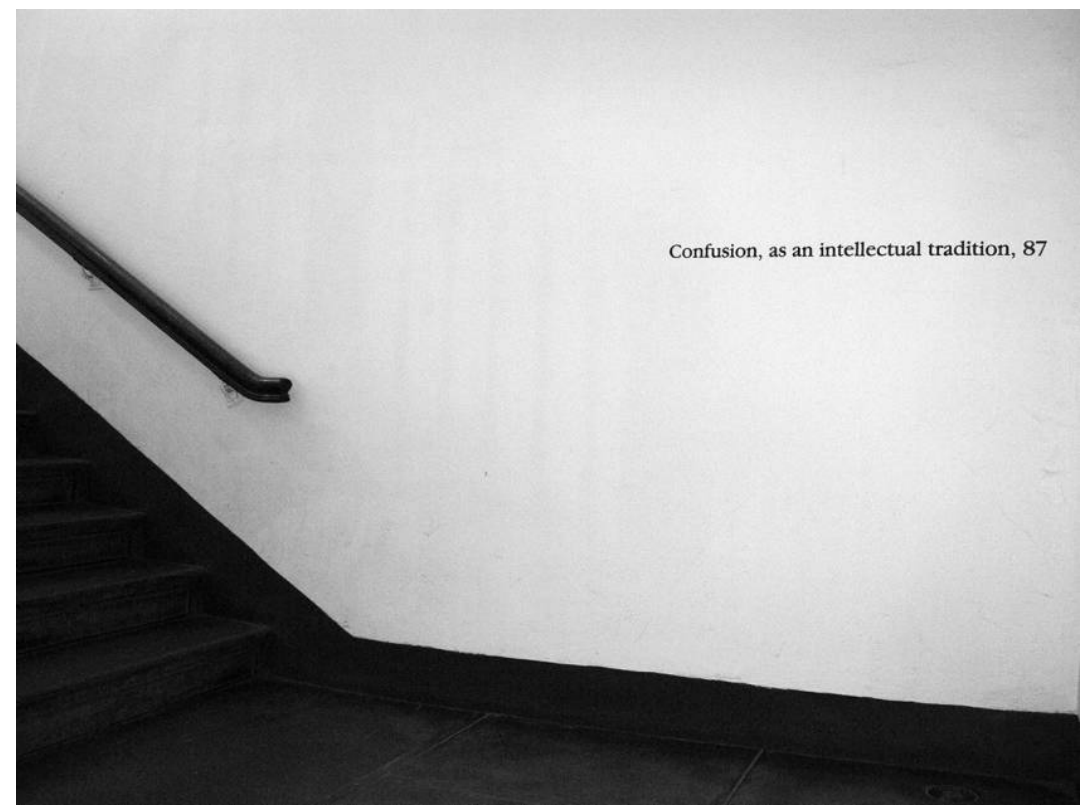

This content downloaded from 141.014.238.123 on April 15, 2019 01:46:56 AM All use subject to University of Chicago Press Terms and Conditions (http://www.journals.uchicago.edu/t-and-c). 


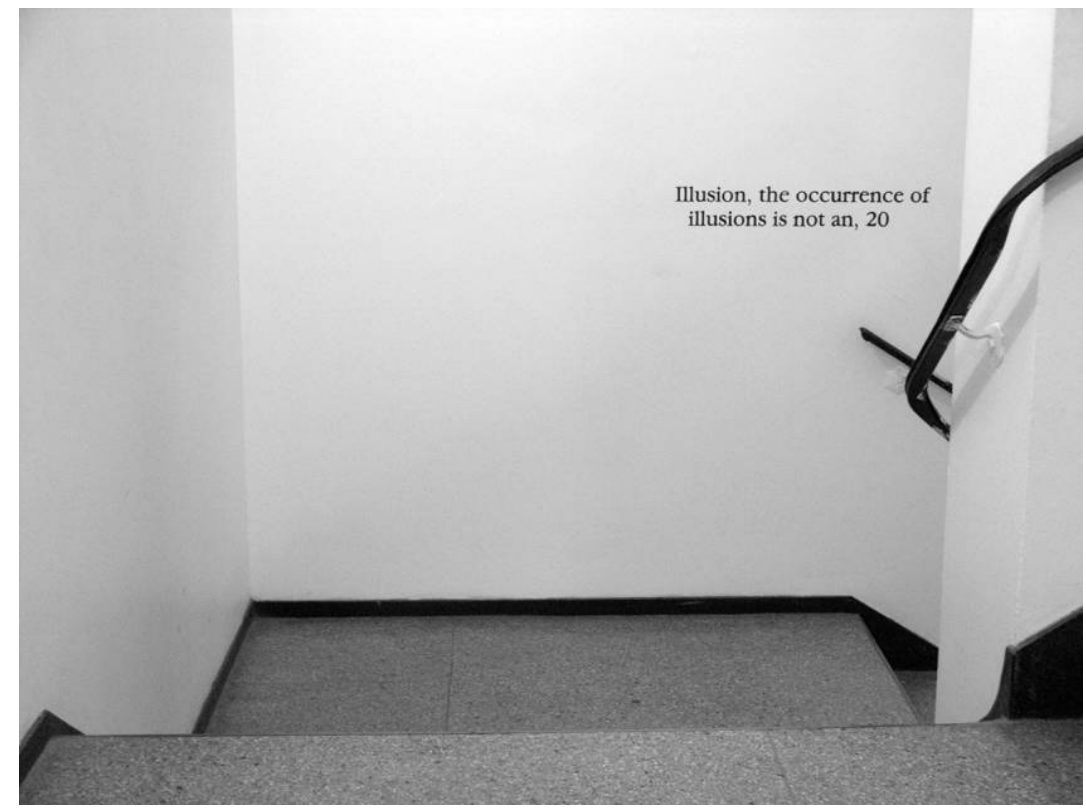

This content downloaded from 141.014.238.123 on April 15, 2019 01:46:56 AM All use subject to University of Chicago Press Terms and Conditions (http://www.journals.uchicago.edu/t-and-c). 